\title{
A MCDM APPROACH TO ASSESSING NPD PROBLEMS
}

\author{
UDC: $519.863: 510.644$ \\ Original Scientific Paper \\ Sanja PUZOVIĆ1, Jasmina VESIĆ VASOVIĆ ${ }^{2}$, Vladan PAUNOVIĆ ${ }^{2}$, Zoran NEŠIĆ \\ ${ }^{1}$ University of Kragujevac, Faculty of Technical Sciences Čačak, 32000 Čačak, Svetog Save 65, Republic of Serbia \\ E-mail: sanja.puzovic@,ftn.kg.ac.rs \\ ${ }^{2}$ University of Kragujevac, Faculty of Technical Sciences Čačak, 32000 Čačak, Svetog Save 65, Republic of Serbia
}

Paper received: 20.04.2019; Paper accepted: 06.05.2019.

\begin{abstract}
Developing new products is an essential strategy tool in achieving a company's comparative advantages and its sustainable development. The problems that may occur during this process may lead to inefficiency and failure in the market, and thus also to poorer organizational performance. Accordingly, recognizing and analyzing NPD problems in a proper way is of exceptional importance for sustaining a company's growth and increasing its profitability. The paper proposes a Multi-Criteria Decision-Making (MCDM) methodology for recognizing and prioritizing the problems that may occur during the process of a New Product Development (NPD). The proposed approach is based on the Analytic Hierarchy Process (AHP) methodology, which enables the assessment of an impact of these problems on the success of the NPD; the AHP method is also integrated with the fuzzy set theory, which is aimed at avoiding the problem of uncertainties and ambiguities. The possibilities of the application of proposed methodology are illustrated in the case of a company manufacturing corrugated paper and special cardboard packaging.
\end{abstract}

Keywords: NPD problems, MCDM, fuzzy AHP.

\section{INTRODUCTION}

New product development is a key aspect of innovation and is one of the most important strategic tools that organizations use to sustain growth and profitability (Kok \& Lightart, 2014). According to Meyer et al. (2001), the success of NPD processes is determined by the numerous external and internal factors that may significantly affect achievable performance. Tang et al. (2011) also point out the fact that NPD is a process associated with great complexity. Hence, in order to ensure its smooth operation, problems involved in NPD process need to be analysed in a proper manner.

Within the current NPD literature, there are many researches who are focused on discovering and analysing the problems that NPD teams are faced with during the new product development process, which on their part significantly influences the success of these processes (Shaw et al., 2005; Choi \& Ahn, 2010; Colvin \& Maravelias, 2011; Gon \& Choi, 2012; Ahmad et al., 2013). Park et al. (2011) also indicate that the problems that may occur during NPD need to be recognized and their impact on the success of the NPD needs to be measured, too. Due to the importance of this issue, it is necessary to establish dynamic NPD problem identification and assessment support systems in order to successfully deal with the risk factors that may jeopardize the achievement of the expected performances of NPD process. These systems might be based on AHP methodology since it has been widely used as a useful weight estimation technique in many areas, also its expansion by the fuzzy set theory enables successful dealing with uncertainty and ambiguity that is inherent to this problem.

The fuzzy AHP method is a widely used method in modelling various business problems under fuzzy environment. Butdeea and Phuangsaleeb (2019) presented the framework for uncertain risk management modelling for the bus body manufacturing supply chain based on the Fuzzy AHP, whereas Shaygan and Testik (2019) applied this method to prioritization and selection of improvement projects for a poor performing 
appointment system at a hospital. Ilbahar et al. (2018) proposed a novel approach to risk assessment for occupational health and safety based on the combination of the fuzzy AHP and fuzzy inference system. Authors Aydın and Kahraman (2018) developed the AHP-based fuzzy multi-criteria decision-making approach to measuring the performance excellence of firms applying for the Malcolm Baldrige National Quality Award. In the study (Ly et al., 2018) the fuzzy AHP-based approach as a methodology for evaluating the influential factors in building successful Internet of Things (IoT) system for IoTrelated enterprises is proposed. Kusumawardani and Agintiara (2015) applied the fuzzy AHP method in order to weight the relative importance of criteria within the process of the human resource manager selection.

\section{THE PROPOSED METHODOLOGY}

There are many researches and studies in the literature that are dealing with identifying and analysing problems that can occur during the NPD process, from different aspects, as well as designing guidelines for their modelling. Galli (2017) highlights the major types of problems as risk factors in NDP processes, as well as what are some of the more common risk management and process tools and what managerial implications may arise. The study (Echeveste et al., 2017) was conducted in order to identify common NPD problems, the result of this research is an alternative way to propose practices that can potentially eliminate specific NPD process problems. $\mathrm{Hu}$ et al. (2017) also investigate which factors contribute to NPD process failure, on the other hand, Salavati et al. (2016) investigate the relationship between technological, marketing, organizational and commercialization risk management on NPD performance.

Despite all these studies dealing with identification and analysis of NPD problems, there is a lack of researches aimed at developing approaches to the prioritization of NPD problems based on their impact on the success of the process by applying weight estimation technique. The methodology proposed in this paper aims to support the process of assessing the impact of the problems encountered in NPD process for it to be successful by applying the AHP method used to assess the influence of identified problems on the success of NPD process. The proposed model is expanded by the fuzzy set theory so as to successfully deal with uncertainty due to imprecision and ambiguity. The prioritization process will be carried out by applying the extent analysis method developed by Chang (1992; 1996).

\section{The Fuzzy Analytic Hierarchical Process}

The Analytic Hierarchical Process (AHP) (Saaty, 1980) is one of the most widely used MCDM methods enabling us to solve the most complex decision-making problems by structuring such problems into a hierarchy of decision-making elements (the goal, the criteria, and the alternatives), and by systematically evaluating them by means of pairwise comparison. The fuzzy set theory was introduced within the traditional AHP method by Zadeh (1965) in order to successfully cope with the ambiguity and vagueness of an expert's judgments. In this paper, the assessment of the influence of the considered NPD problems on the success of this process will be carried out by applying the extent analysis method developed by Chang (1992; 1996). The procedure of the extent analysis method is presented below and the concept of from the paper by Chang (1996) will be used.

Firstly, it is necessary to establish a fuzzy pairwise comparison matrix $A_{i j}=\left\{a_{i j}\right\}_{n \times m}$, with the $n$ goals and the $m$ attributes, as reads in Eq. (1).

$$
A_{i j}=\left|\begin{array}{cccc}
1 & a_{12} & \ldots & a_{1 m} \\
a_{21} & 1 & \ldots & a_{2 m} \\
\ldots & \ldots & \ldots & \ldots \\
a_{n 1} & a_{n 2} & \cdots & a_{n m}
\end{array}\right|
$$

The elements of the fuzzy pairwise comparison matrix $\left(a_{i j}\right)$ which represent the preference of factor $i$ over the factor $j$ are expressed as language statements. Each language statement is assigned a numerical value which, within the conventional AHP method, is given as the exact value and is determined according to Saaty's nine-point scale, whereas within the fuzzy AHP method, due to the uncertainties of expressed preferences, it is given in the form of a triangular fuzzy number adopted from the fuzzy evaluation scale (Table 1). In this way, the imprecise and vague nature of linguistic assessments is successfully avoided. 
Table 1: The fuzzified evaluation scale (Chang, 1992)

\begin{tabular}{|c|l|c|}
\hline Fuzzy number & Linguistic term & $\begin{array}{c}\text { The scale of the fuzzy } \\
\text { number }\end{array}$ \\
\hline$' 1$ & Equally important & $(1,1,1)$ \\
\hline 3 & Weakly important & $(2,3,4)$ \\
\hline 55 & Essentially important & $(4,5,6)$ \\
\hline$' 7$ & Very strongly important & $(6,7,8)$ \\
\hline 9 & Absolutely important & $(7,8,9)$ \\
\hline$' 2,4, ' 6, ' 8$ & Intermediate values (' $x)$ & $(x-1, x, x+1)$ \\
\hline $1 / ' x$ & Between two adjacent judgments & $(1 / x+1,1 / x, 1 / x-1)$ \\
\hline
\end{tabular}

Figure 1. represents a fuzzy triangular number which is defined by three real numbers expressed as a triple $(l, m, u), l \leq m \leq u$ for describing a fuzzy event.

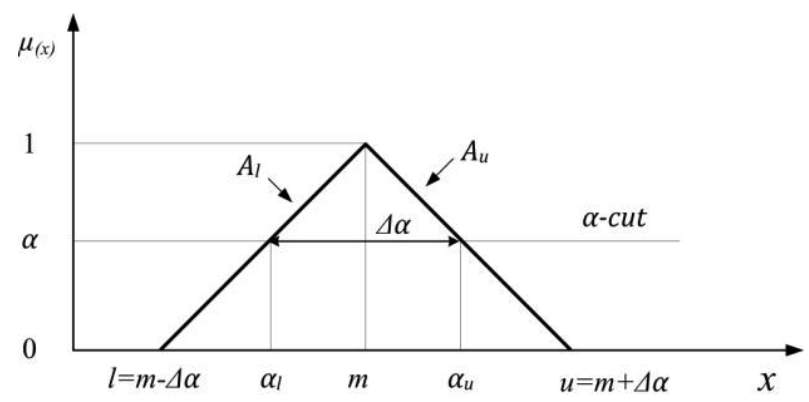

Figure 1: A triangular fuzzy number

Where $\alpha$ represents the degree of the uncertainty; $\Delta \alpha=\alpha_{u}-\alpha_{l} ; \quad \alpha_{l}$ is the ordinate of the intersection point between $\alpha$-cut and $A_{l}$, and $\alpha_{u}$ is the ordinate of the intersection point between $\alpha-$ cut and $A_{u} ; A_{l}$ denotes the left side representation and $A_{u}$ the right side representation of a triangular fuzzy number as shown in Figure 1.

Triangular fuzzy numbers are otherwise referred to as "linear" because they have a linear membership function, defined as in Eq. (2).

$$
\mu_{M}(x)=\left\{\begin{array}{l}
\frac{x-l}{m-l}, x \in[l, m], \\
\frac{x-u}{m-u}, x \in[m, u], \\
0, \quad \text { otherwise }
\end{array}\right.
$$

There are three operations applicable on the triangular fuzzy numbers: addition (3), multiplication (4), and inverse (5). If $a_{1}=\left(l_{1}, m_{1}, u_{1}\right)$ and $a_{2}=\left(l_{2}, m_{2}, u_{2}\right)$, then:

$$
\begin{aligned}
& a_{1} \oplus a_{2}=\left(l_{1}, m_{1}, u_{1}\right) \oplus\left(l_{2}, m_{2}, u_{2}\right)=\left(l_{1}+l_{2}, m_{1}+m_{2}, u_{1}+u_{2}\right) \\
& a_{1} \otimes a_{2}=\left(l_{1}, m_{1}, u_{1}\right) \otimes\left(l_{2}, m_{2}, u_{2}\right)=\left(l_{1} \cdot l_{2}, m_{1} \cdot m_{2}, u_{1} \cdot u_{2}\right) \\
& a_{1}^{-1}=\left(l_{1}, m_{1}, u_{1}\right)^{-1}=\left(\frac{1}{u_{1}}, \frac{1}{m_{1}}, \frac{1}{l_{1}}\right)
\end{aligned}
$$

In case there are a group of experts involved in the prioritization process, their respective individual judgments in the form of individual fuzzy pairwise matrices might be aggregated by applying the fuzzy geometric mean method (6). This creates an aggregate pairwise comparison matrix,

$$
a_{i j}=\left(\prod_{i=1}^{n} a_{i j k}\right)^{\frac{1}{n}}=\left\{a_{i j}\right\}
$$

where $a_{i j k}$ is fuzzy relative importance according to the $k^{\text {th }}$ expert's opinion, and $n$ is the number of experts.

The next step implies the computation of a fuzzy synthetic extent value $\left(S_{i}\right)$ for each of the factors from the aggregate fuzzy pairwise comparison matrix according to Eq. (7), 


$$
S_{i}=\sum_{j=1}^{m} a_{i j} \otimes\left[\sum_{i=1}^{n} \sum_{j=1}^{m} a_{i j}\right]^{-1}
$$

where $\sum_{j=1}^{m} a_{i j}$ is calculated by using fuzzy operator $\otimes(3)$, as is given in Eq. (8).

$$
\begin{aligned}
& \sum_{j=1}^{m} a_{i j}=\left(l_{i 1}, m_{i 1}, u_{i 1}\right) \oplus\left(l_{i 2}, m_{i 2}, u_{i 2}\right) \oplus \ldots \oplus\left(l_{i m}, m_{i m}, u_{i m}\right)= \\
& =\left(\sum_{j=1}^{m} l_{i j}, \sum_{j=1}^{m} m_{i j}, \sum_{j=1}^{m} u_{i j},\right)=\left(l_{i}, m_{i}^{\prime}, u_{i}^{\prime}\right)
\end{aligned}
$$

and $\sum_{i=1}^{n} \sum_{j=1}^{m} a_{i j}$ is determined by using the fuzzy addition operation $\otimes(3)$, as is given in Eq. (9)

$$
\begin{aligned}
& \sum_{i=1}^{n} \sum_{j=1}^{m} a_{i j}=\sum_{i=1}^{n}\left(\sum_{j=1}^{m} l_{i j}, \sum_{j=1}^{m} m_{i j}, \sum_{j=1}^{m} u_{i j},\right)=\sum_{i=1}^{n}\left(\left(l_{i}^{\prime}, m_{i}^{\prime}, u_{i}^{\prime}\right)\right)= \\
& =\left(l_{1}, m_{1}, u_{1}^{\prime}\right) \oplus\left(l_{2}, m_{2}, u_{2}^{\prime}\right) \oplus \ldots \oplus\left(l_{n}, m_{n}, u_{n}^{\prime}\right)=\left(\sum_{i=1}^{n} l_{i}, \sum_{i=1}^{n} m_{i}, \sum_{i=1}^{n} u_{i}^{\prime}\right)
\end{aligned}
$$

and $\left[\sum_{i=1}^{n} \sum_{j=1}^{m} a_{i j}\right]^{-1}$ is determined by using the fuzzy inverse operation (5), which is shown in Eq. (10).

$$
\left[\sum_{i=1}^{n} \sum_{j=1}^{m} a_{i j}\right]^{-1}=\left[\sum_{i=1}^{n} l_{i}, \sum_{i=1}^{n} m_{i}, \sum_{i=1}^{n} u_{i}^{\prime}\right]^{-1}=\left(\frac{1}{\sum_{i=1}^{n} u_{i},}, \frac{1}{\sum_{i=1}^{n} m_{i}}, \frac{1}{\sum_{i=1}^{n} l_{i}}\right)
$$

From the previous relation, the $S_{i}$ is obtained as in Eq. (11), by using fuzzy multiplication operation given in Eq. (4)

$$
\begin{aligned}
& S_{i}=\left(l_{i}^{\prime}, m_{i}^{\prime}, u_{i}^{\prime}\right) \otimes\left(\frac{1}{\sum_{i=1}^{n} u_{i}^{\prime}}, \frac{1}{\sum_{i=1}^{n} m_{i}^{\prime}}, \frac{1}{\sum_{i=1}^{n} l_{i}^{\prime}}\right)= \\
& =\left(l_{i}^{\prime} \otimes \frac{1}{\sum_{i=1}^{n} u_{i}^{\prime}}, m_{i}^{\prime} \otimes \frac{1}{\sum_{i=1}^{n} m_{i}^{\prime}}, u_{i}^{\prime} \otimes \frac{1}{\sum_{i=1}^{n} l_{i}^{\prime}}\right)\left(\frac{l_{i}^{\prime}}{\sum_{i=1}^{n} u_{i}^{\prime}}, \frac{m_{i}^{\prime}}{\sum_{i=1}^{n} m_{i}{ }^{\prime}}, \frac{u_{i}^{\prime}}{\sum_{i=1}^{n} l_{i}^{\prime}}\right)=\left(l_{i}, m_{i}, u_{i}\right)
\end{aligned}
$$

After that, it is necessary to determine the degree of the possibility with which $S_{2}=\left(l_{2}, m_{2}, u_{2}\right) \geq$ $S_{1}=\left(l_{1}, m_{1}, u_{1}\right)$, which is possible to define as in Eq. (12).

$$
V\left(S_{2} \geq S_{1}\right)=\sup \left[\min \left(\mu_{S_{1}}(x),\left(\mu_{S_{2}}(y)\right)\right]\right.
$$


Since $S_{1}$ and $S_{2}$ are convex fuzzy numbers and by applying the principle of the comparison of fuzzy numbers, we have the following

$V\left(S_{1} \geq S_{2}\right)=1$, iff $m_{1} \geq m_{2}$, and $V\left(S_{2} \geq S_{1}\right)=\operatorname{hgt}\left(S_{1} \cap S_{2}\right)=\mu_{S_{1}}(d)$.

It can also be expressed as in Eq. (13),

$$
V\left(S_{2} \geq S_{1}\right)=h g t\left(S_{1} \cap S_{2}\right)=\mu_{S_{1}}(d)=\left\{\begin{array}{cc}
1, & \text { if } m_{2} \geq m_{1} \\
0, & \text { if } l_{1} \geq u_{2} \\
\frac{l_{1}-u_{2}}{\left(m_{2}-u_{2}\right)-\left(m_{1}-l_{1}\right)} & \text { oterwise }
\end{array}\right.
$$

where $d$ represents the value of the ordinate that corresponds with the highest point of the intersection between $S_{1}$ and $S_{2}$, as is shown in the Figure 2 which illustrates the Eq. (14).

$$
V\left(S_{2} \geq S_{1}\right)=\operatorname{hgt}\left(S_{1} \bigcap_{2}\right)=\mu_{S_{1}}(d)
$$

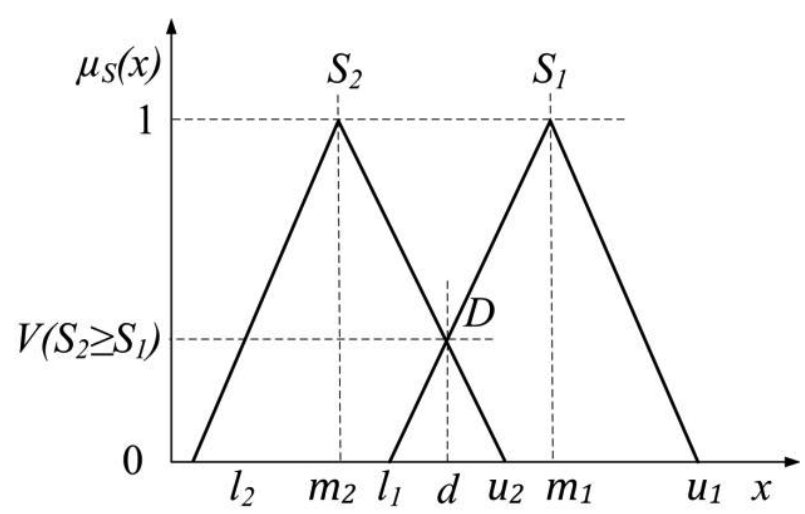

Figure 2: The intersection between $S 1$ and $S 2$ and their degree of possibility (Chang, 1996)

By funding the preference of $S_{1}$ and $S_{k}$, the degree of the possibility of obtaining a convex fuzzy number can be calculated as follows:

$$
\begin{aligned}
& \mathrm{V}\left(S \geq S_{1}, S_{2}, \ldots, S_{n}\right)= \\
& =\left[V\left(S \geq S_{1}\right) \text { and } \ldots \text { and } V\left(S \geq S_{n}\right)\right]= \\
& =\min V\left(S \geq S_{i}\right)(i=1,2, \ldots, n)
\end{aligned}
$$

If $d^{\prime}\left(A_{i}\right)=\min \min V\left(S_{i} \geq S_{k}\right)$, $(k=1,2,3, \ldots, n ; k \neq i)$ then the weight vector is given by:

$$
W^{\prime}=\left(d^{\prime}\left(A_{1}\right), d^{\prime}\left(A_{2}\right) \ldots d^{\prime}\left(A_{n}\right)\right)
$$

It is further necessary to obtain a normalized weight vector by defuzzifying $W^{\prime}$, Eq. (17).

$$
W=\left(d\left(A_{1}\right), d\left(A_{2}\right) \ldots d\left(A_{n}\right)\right)
$$

\section{A CASE STUDY}

In this section, the possibility of application of the proposed methodology is illustrated in the case of a company manufacturing corrugated paper and special cardboard packaging, supportive of the problem prioritization process companies are faced with while performing NPD processes. The influence these problems, as risk factors, had on the success of the NPD project was estimated by applying the AHP method integrated with the fuzzy set theory. The proposed methodology is presented in Figure 3.

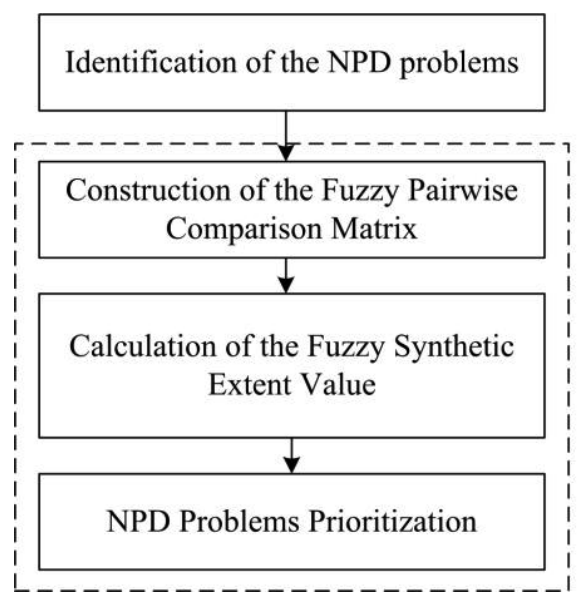

Fuzzy AHP

Figure 3: The process of the NPD problem prioritization

A group of four experts was involved throughout the evaluation process. These experts are competent members of the company's NPD team and are significantly experienced in new product development activities. 
The first step implied the identification of potential problems (risk factors) encountered during NPD process. Based on the review of the relevant literature (Shaw et al., 2005; Teller \& Kock, 2013; Bowers \& Khorakian, 2014; Oehmen et al., 2014; Thangamani, 2016) and the study of the specificity of NPD process, the basic problems that had a significant influence on the success of this process were identified and a list of them was made. The experts involved in the evaluation process extracted the problems they had encountered in the new product development processes which they participated in out of the established list of potential problems.

Once the problems that one could come across during NPD processes have been identified, it is necessary that their impact on the success of NPD should be assessed by applying the fuzzy AHP methodology.

The process of the prioritization of NPD problems by applying fuzzy AHP method begins with the construction of individual fuzzy pairwise comparison matrices (1) by each expert involved in the evaluation process. Experts from pairwise comparison matrices by expressing their subjective preferences regarding the impact of the considered NPD problems on the success of this process. Those subjective preferences are expressed in the form of language statements (e.g. Equally important, Weakly important, Essentially important, Very strongly important...) according to the scale given in Table 1. Those statements are further represented by a triangular fuzzy number according to the fuzzy scale presented in Table 1. In Table 2, an example of the individual fuzzy comparison matrix of NPD problems for Expert 1 is presented.

By calculating the fuzzy geometric mean of the individual matrices of the experts involved in the NPD problem evaluation process by Eq. (6), an aggregated fuzzy pairwise comparisons matrix was formed, which is presented in Table 3.

Table 2: The fuzzy comparison matrix of NPD problems for Expert 1

\begin{tabular}{|c|l|c|c|c|c|c|c|}
\hline \multicolumn{2}{|c|}{ NPD problem } & $\mathbf{P}_{1}$ & $\mathbf{P}_{2}$ & $\mathbf{P}_{3}$ & $\mathbf{P}_{4}$ & $\mathbf{P}_{5}$ & $\mathbf{P}_{6}$ \\
\hline $\mathbf{P}_{\mathbf{1}}$ & Lack of financial resources & $(1,1,1)$ & $(4,5,6)$ & $(2,3,4)$ & $(4,5,6)$ & $(2,3,4)$ & $(1,1,1)$ \\
\hline $\mathbf{P}_{2}$ & Poor technical competencies & $(0.17,0.2,0.25)$ & $(1,1,1)$ & $(0.25,0.33,0.5)$ & $(2,3,4)$ & $(2,3,4)$ & $(0.25,0.33,0.5)$ \\
\hline $\mathbf{P}_{3}$ & $\begin{array}{l}\text { Poor cross-functional } \\
\text { collaboration }\end{array}$ & $(0.25,0.33,0.5)$ & $(2,3,4)$ & $(1,1,1)$ & $(0.17,0.2,0.25)$ & $(4,5,6)$ & $(0.25,0.33,0.5)$ \\
\hline $\mathbf{P}_{4}$ & $\begin{array}{l}\text { Unclear NPD objectives } \\
\text { and strategy }\end{array}$ & $(0.17,0.2,0.25)$ & $(0.25,0.33,0.5)$ & $(4,5,6)$ & $(1,1,1)$ & $(1,1,1)$ & $(0.25,0.33,0.5)$ \\
\hline $\mathbf{P}_{5}$ & $\begin{array}{l}\text { Inadequate control system } \\
\text { in NPD process }\end{array}$ & $(0.25,0.33,0.5)$ & $(0.25,0.33,0.5)$ & $(0.17,0.2,0.25)$ & $(1,1,1)$ & $(1,1,1)$ & $(1,1,1)$ \\
\hline $\mathbf{P}_{\mathbf{6}}$ & $\begin{array}{l}\text { Changing demands and } \\
\text { unpredictable customer } \\
\text { reactions }\end{array}$ & $(1,1,1)$ & $(2,3,4)$ & $(2,3,4)$ & $(2,3,4)$ & $(1,1,1)$ & $(1,1,1)$ \\
\hline
\end{tabular}

Table 3: An aggregated fuzzy comparison matrix of NPD problems

\begin{tabular}{|c|l|c|c|c|c|c|c|}
\hline \multicolumn{2}{|c|}{ NPD problems } & $\mathbf{P}_{1}$ & $\mathbf{P}_{\mathbf{2}}$ & $\mathbf{P}_{3}$ & $\mathbf{P}_{4}$ & $\mathbf{P}_{5}$ & $\mathbf{P}_{\mathbf{6}}$ \\
\hline $\mathbf{P}_{\mathbf{1}}$ & Lack of financial resources & $(1,1,1)$ & $(1.14,1.7,2.06)$ & $(1,1.32,1.68)$ & $(1.41,1.97,2.63)$ & $(2,3,4)$ & $(0.76,0.88,1)$ \\
\hline $\mathbf{P}_{2}$ & Poor technical competencies & $(0.49,0.59,0.71)$ & $(1,1,1)$ & $(0.71,0.86,1.11)$ & $(1.41,1.73,2)$ & $(0.71,1,1.41)$ & $(0.45,0.58,0.78)$ \\
\hline $\mathbf{P}_{\mathbf{3}}$ & $\begin{array}{l}\text { Poor cross-functional } \\
\text { collaboration }\end{array}$ & $(0.59,0.76,1)$ & $(0.9,1.16,1.41)$ & $(1,1,1)$ & $(0.58,0.77,1)$ & $(1.68,2.24,2.91)$ & $(0.84,1.14,1.57)$ \\
\hline $\mathbf{P}_{\mathbf{4}}$ & $\begin{array}{l}\text { Unclear NPD objectives } \\
\text { and strategy }\end{array}$ & $(0.38,0.51,0.71)$ & $(0.5,0.58,0.71)$ & $(1,1.29,1.73)$ & $(1,1,1)$ & $(0.5,0.61,0.76)$ & $(0.23,0.29,0.42)$ \\
\hline $\mathbf{P}_{\mathbf{5}}$ & $\begin{array}{l}\text { Inadequate control system } \\
\text { in NPD process }\end{array}$ & $(0.25,0.33,0.5)$ & $(0.71,1,1.41)$ & $(0.34,0.45,0.59)$ & $(1.32,1.63,2)$ & $(1,1,1)$ & $(0.5,0.58,0.71)$ \\
\hline $\mathbf{P}_{\mathbf{6}}$ & $\begin{array}{l}\text { Changing demands and } \\
\text { unpredictable customer } \\
\text { reactions }\end{array}$ & $(1,1.14,1.32)$ & $(1.28,1.73,2.21)$ & $(0.64,0.88,1.19)$ & $(2,2.59,3.13)$ & $(1.41,1.73,2)$ & $(1,1,1)$ \\
\hline
\end{tabular}

The next step implied the computation of fuzzy synthetic extent values $\left(S_{i}\right)$ for each of the considered NPD problems, the values being derived from the aggregate fuzzy pairwise comparison matrix (Table 3) according to Eq. (11). The calculation of the $S_{i}$ is accounted for below, the results being listed in Table 4 .

$$
\begin{aligned}
& S_{1}=(6.83,8.98,11.37) \otimes(33.01,41.03,50.7)^{-1}=(0.13,0.22,0.34) \\
& S_{2}=(4.31,5.18,6.23) \otimes(33.01,41.03,50.7)^{-1}=(0.09,0.13,0.19)
\end{aligned}
$$




$$
\begin{aligned}
& S_{3}=(4.76,5.93,7.33) \otimes(33.01,41.03,50.7)^{-1}=(0.09,0.14,0.22) \\
& S_{4}=(3.38,3.99,4.91) \otimes(33.01,41.03,50.7)^{-1}=(0.07,0.1,0.15) \\
& S_{5}=(3.62,4.41,5.51) \otimes(33.01,41.03,50.7)^{-1}=(0.07,0.11,0.17) \\
& S_{6}=(6.33,8.07,9.85) \otimes(33.01,41.03,50.7)^{-1}=(0.12,0.20,0.30)
\end{aligned}
$$

Table 4: The Synthetic Extent Values

\begin{tabular}{|l|c|}
\hline \multicolumn{1}{|c|}{ NPD problems } & $\begin{array}{c}\text { Synthetic } \\
\text { Extent Value }\end{array}$ \\
\hline Lack of financial resources & $(0.13,0.22,0.34)$ \\
\hline Poor technical competencies & $(0.09,0.13,0.19)$ \\
\hline Poor cross-functional collaboration & $(0.09,0.14,0.22)$ \\
\hline Unclear NPD objectives and strategy & $(0.07,0.1,0.15)$ \\
\hline $\begin{array}{l}\text { Inadequate control system } \\
\text { in NPD process }\end{array}$ & $(0.07,0.11,0.17)$ \\
\hline $\begin{array}{l}\text { Changing demands and } \\
\text { unpredictable consumer reactions }\end{array}$ & $(0.12,0.20,0.30)$ \\
\hline
\end{tabular}

At the final step, the NPD problem prioritization process was carried out. This process was based on the calculation of the minimum degree of the possibility of the superiority of the impact of one problem over another $\left(V\left(S_{2} \geq S_{1}\right)\right)$. The calculation was carried out according to Eq. (13). The calculation for the problem $P_{5}$ is shown below.

$$
V\left(S_{5} \geq S_{1}\right)=\frac{(0.13-0.17)}{(0.11-0.17)-(0.22-0.13)}=0.22
$$

$$
\begin{aligned}
& V\left(S_{5} \geq S_{2}\right)=\frac{(0.09-0.17)}{(0.11-0.17)-(0.13-0.09)}=0.81 \\
& V\left(S_{5} \geq S_{3}\right)=\frac{(0.09-0.17)}{(0.11-0.17)-(0.14-0.09)}=0.66 \\
& V\left(S_{5} \geq S_{4}\right)=1 \\
& V\left(S_{5} \geq S_{6}\right)=\frac{(0.12-0.17)}{(0.11-0.17)-(0.12-0.20)}=0.32
\end{aligned}
$$

The same procedure was repeated for the other remaining problems. According to the obtained values, a possibilities matrix was established, and the matrix is presented in Table 5.

Based on the possibilities matrix, the weight vectors $\left(W^{\prime}\right)$ were obtained according to Eq. (16), and normalized weight vectors $(W)$ that represent the impact of each considered problem on the success of NPD were obtained according to Eq. (17). The results are accounted for in Table 6.

Table 5: The possibilities matrix $\left(V\left(S_{2} \geq S_{1}\right)\right)$

\begin{tabular}{|l|c|c|c|c|c|c|}
\hline \multirow{2}{*}{\multicolumn{1}{|c|}{ NPD problems }} & \multicolumn{6}{c|}{ Degree of the possibility of superiority } \\
\cline { 2 - 8 } & $\boldsymbol{P}_{\mathbf{1}}$ & $\boldsymbol{P}_{\mathbf{2}}$ & $\boldsymbol{P}_{3}$ & $\boldsymbol{P}_{\mathbf{4}}$ & $\boldsymbol{P}_{5}$ & $\boldsymbol{P}_{6}$ \\
\hline Lack of financial resources & - & 1 & 1 & 1 & 1 & 1 \\
\hline Poor technical competencies & 0.37 & - & 0.84 & 1 & 1 & 0.48 \\
\hline Poor cross-functional collaboration & 0.54 & 1 & - & 1 & 1 & 0.65 \\
\hline Unclear NPD objectives and strategy & 0,1 & 0.69 & 0.54 & - & 0.88 & 0.19 \\
\hline Inadequate control system in NPD process & 0.22 & 0.81 & 0.66 & 1 & - & 0.32 \\
\hline $\begin{array}{l}\text { Changing demands and unpredictable } \\
\text { consumer reactions }\end{array}$ & 0.88 & 1 & 1 & 1 & 1 & - \\
\hline
\end{tabular}

Table 6: The weight vectors and normalized weight vectors

\begin{tabular}{|l|c|c|}
\hline \multicolumn{1}{|c|}{ NPD problems } & $\begin{array}{c}\text { Weight vector } \\
\left(\boldsymbol{W}^{\prime}\right)\end{array}$ & $\begin{array}{c}\text { Normalized weight } \\
\text { vector }(\boldsymbol{W})\end{array}$ \\
\hline Lack of financial resources & 1.000 & 0.321 \\
\hline Poor technical competencies & 0.368 & 0.118 \\
\hline Poor cross-functional collaboration & 0.540 & 0.173 \\
\hline Unclear NPD objectives and strategy & 0.102 & 0.033 \\
\hline Inadequate control system in NPD process & 0.224 & 0.072 \\
\hline $\begin{array}{l}\text { Changing demands and unpredictable consumer } \\
\text { reactions }\end{array}$ & 0.880 & 0.283 \\
\hline
\end{tabular}




\section{DISCUSSION}

The results obtained by the evaluation process are indicative of the fact that the most significant problem the members of the company's NPD team had encountered during the NPD process was Lack of financial resources $(W=0.321)$. Also, Changing demands and unpredictable consumer reactions, whose estimated relative weight was $W=0.283$, was also singled out as a very significant problem. The problems such as Poor cross-functional cooperation (0.173) and Poor technical competence (0.118) had a significant impact on the success of NPD processes conducted in this company, too. The problems such as Inadequate control system in the NPD process (0.072) and Unclear NPD objectives and strategy (0.032) are not the problems with a significant impact on the success of NPD processes in the case of this company. Those finding result will help the NPD team of the company to assign priority and conceive actions for NPD problems solving in accordance with the estimated impact they have on the success of the NPD projects.

Although there are many researches and studies in the literature that are dealing with identifying and analysing problems that can occur during the NPD process from different aspects, as well as designing guidelines for their modelling, there is a lack of research regarding the prioritization of NPD problems based on their impact on the success of the process. The main contribution of the paper is a proposal of the effective approach to prioritizing NPD problems based on fuzzy AHP methodology, applying of this method can be of significant help in improving the performance of the process of developing new products. By using fuzzy set theory, the qualitative judgment can be qualified to reduce assessment bias in the assessment process.

\section{CONCLUSION}

In this paper, an approach to prioritization of the problems that companies are faced with during the implementation of the NPD process is proposed. The proposed framework is based on the AHP method extended by the fuzzy set theory was proposed with the aim of successfully dealing with ambiguity.

Based on the review of the relevant literature and the experiences of the experts involved in the evaluation process, a list of the problems that may be encountered during the new product development process was identified, while simultaneously the impact of these problems, as risk factors, on the success of the NPD project was estimated by using the fuzzy AHP method. The proposed methodology was illustrated in the case of a company manufacturing corrugated paper and special cardboard packaging.

According to the findings, NPD problems with a significant impact on the success of a new product development which the members of the company's NPD team had come across during the NPD process are as follows: Lack of financial resources and Changing demands and unpredictable consumer reactions, as well as Poor crossfunctional cooperation and Poor technical competence.

This approach may help the NPD team of the company to assign priority and conceive actions for NPD problems solving in accordance with the estimated impact they have on the success of the NPD projects.

Further research aimed at problem improvement may be the development of the approach that will enable interpretation of complex non-linear relationships among considered problems, such as approaches based on Analytic Network Process (AHP) methodology.

\section{ACKNOWLEDGEMENTS}

This paper was supported by the research project TR35017 of the Ministry of Education, Science and Technological Development of the Republic of Serbia.

\section{REFERENCES}

Ahmad, S., Mallick, D. N., \& Schroeder, R. G. (2013). New product development: impact of project characteristics and development practices on performance. Journal of Product Innovation Management, 30(2), 331-348

Aydın, S., \& Kahraman, C. (2019). Evaluation of firms applying to malcolm baldrige national quality award: A modified fuzzy AHP method. Complex \& Intelligent Systems, 5(1), 53-63.

Bowers, J., \& Khorakian, A. (2014). Integrating risk management in the innovation project. European Journal of innovation management, 17(1), 25-40.

Butdeea, S., \& Phuangsaleeb, P. (2019). Uncertain risk assessment modelling for bus body manufacturing supply chain using AHP and fuzzy AHP. Procedia Manufacturing, 30, 663-670. 
Chang, D. Y. (1992). Extent analysis and synthetic decision. Optimization Techniques and Applications, 1(1), 352-355.

Chang, D.Y. (1996). Applications of the extent analysis method on fuzzy AHP. European Journal of Operational Research, 95(3), 649-655.

Choi, H. G., \& Ahn, J. (2010). Risk analysis models and risk degree determination in new product development: A case study. Journal of Engineering and Technology Management, 27(1-2), 110-124.

Colvin, M. \& Maravelias, C.T. (2011). R\&D pipeline management: task interdependencies and risk management. European Journal of Operational Research, 215(3), 616-628.

Echeveste, M. E. S., Rozenfeld, H., \& Fettermann, D. D. C. (2017). Customizing practices based on the frequency of problems in new product development process. Concurrent Engineering, 25(3), 245-261.

Galli, B. J. (2017). The effective approach of managing risk in new product development (NPD). International Journal of Applied Management Sciences and Engineering (IJAMSE), 4(2), 27-40.

Gon, C.H., \& Choi, D. (2012). Framework development for optimizing responses to NPD risks. International Journal of Management Science and Engineering Management, 7(3), 229-240.

Hu, Y., McNamara, P., \& Piaskowska, D. (2017). Project suspensions and failures in new product development: Returns for entrepreneurial firms in co-development alliances. Journal of Product Innovation Management, 34(1), 35-59.

Ilbahar, E., Karaşan, A., Cebi, S., \& Kahraman, C. (2018). A novel approach to risk assessment for occupational health and safety using Pythagorean fuzzy AHP \& fuzzy inference system. Safety Science, 103, 124-136.

Kok, R. A., \& Ligthart, P. E. (2014). Differentiating major and incremental new product development: The effects of functional and numerical workforce flexibility. Journal of Product Innovation Management, 31, 30-42.

Kusumawardani, R. P., \& Agintiara, M. (2015). Application of fuzzy AHP-TOPSIS method for decision making in human resource manager selection process. Procedia Computer Science, 72, 638-646.

Ly, P. T. M., Lai, W. H., Hsu, C. W., \& Shih, F. Y. (2018). Fuzzy AHP analysis of Internet of Things
(IoT) in enterprises. Technological Forecasting and Social Change, 136, 1-13.

Meyer, A., Loch, C.H. \& Pich, M.T. (2001). Managing project uncertainty: from variation to chaos. MIT Sloan Management Review, 43(2), 60-68.

Oehmen, J., Olechowski, A., Kenley, C. R., \& BenDaya, M. (2014). Analysis of the effect of risk management practices on the performance of new product development programs. Technovation, 34(8), 441-453.

Park, S., Kim, J., \& Choi, H. G. (2011). A risk management system framework for new product development (NPD). Economics and Finance Research, 4, 51-56.

Saaty, T. L., (1980). The Analytic Hierarchy Process: planning, Priority setting, resources allocation. New York: McGraw.

Salavati, M., Tuyserkani, M., Mousavi, S. A., Falahi, N., \& Abdi, F. (2016). Improving new product development performance by risk management. Journal of Business \& Industrial Marketing, 31(3), 418-425.

Shaw, N. E., Burgess, T. F., \& De Mattos, C. (2005). Risk assessment of option performance for new product and process development projects in the chemical industry: A case study. Journal of Risk Research, 8(7-8), 693-711.

Shaygan, A., \& Testik, Ö. M. (2019). A fuzzy AHPbased methodology for project prioritization and selection. Soft Computing, 23(4), 1309-1319.

Tang, D., Yang, J. B., Chin, K. S., Wong, Z. S., \& Liu, $X$. (2011). A methodology to generate a belief rule base for customer perception risk analysis in new product development. Expert Systems with Applications, 38(5), 5373-5383.

Teller, J., \& Kock, A. (2013). An empirical investigation on how portfolio risk management influences project portfolio success. International Journal of Project Management, 31(6), 817-829.

Thangamani, G. (2016). Modified approach to risk assessment: A case study on product innovation and development value chain. International Journal of Innovation, Management and Technology, 7(1), 16.

Zadeh, L. A. (1965). Information and control. Fuzzy Sets, 8(3), 338-353. 


\section{VIŠEKRITERIJUMSKI PRISTUP ZA PROCENU PROBLEMA PRI RAZVOJU NOVIH PROIZVODA}

Razvoj novih proizvoda predstavlja ključni strategijski alat za postizanje komparativne prednosti i održivog razvoja kompanije. Problemi koji se mogu pojaviti tokom ovog procesa mogu dovesti do neefikasnosti i slabijeg uspeha na tržištu, a time usloviti i lošije organizacione performanse. Shodno tome, njihovo prepoznavanje i adekvatna analiza mogu biti od izuzetne važnosti za uspostavljanje održivog razvoja i rast profitabilnosti kompanije. U radu je predložen višekriterijumski pristup za prepoznavanje i prioritizaciju problema koji se mogu pojaviti tokom procesa razvoja novih proizvoda. Predloženi pristup je baziran na metodi Analitičkog hijerarhijskog procesa (AHP) koja omogućava procenu uticaja ovih problema na uspeh procesa razvoja novih proizvoda, takođe integracijom fuzzy set teorije u okviru procesa konvencionalne AHP metode omogućeno je izbegavanje neodređenosti i dvosmislenosti koje prate ovaj proces. Predložena metodologija je ilustrovana na primeru kompanije za proizvodnju talasastog papira i specijalne kartonske ambalaže.

Ključne reči: Problemi u razvoju novih proizvoda, Višekriterijumsko odlučivanje, Fuzzy AHP. 